\title{
Tumour necrosis factor alpha production is upregulated in diabetes prone BB rats
}

\author{
H. Rothe, K. Fehsel and H. Kolb \\ Diabetes Research Institute, University of Düsseldorf, Düsseldorf, FRG
}

\begin{abstract}
Summary. Following activation peritoneal macrophages from diabetes prone $\mathrm{BB}$ rats secreted strikingly higher amounts of tumour necrosis factor alpha than found for macrophages from diabetes resistant or normal Wistar rats. Enhanced tumour necrosis factor alpha production was detected prior to the occurrence of insulitis. Cultures of macrophages derived from precursor cells in diabetes prone $\mathrm{BB}$ rat bone marrow also showed upregulated tumour
\end{abstract}

necrosis factor alpha secretion upon challenge with endotoxin and interferon gamma. Tumour necrosis factor alpha hypersecretion may contribute to autoimmune diabetes by affecting thymic and post-thymic T-cell maturation and by promoting pancreatic islet inflammation.

Key words: BB rat, autoimmunity, tumour necrosis factor alpha, macrophages.
The development of Type 1 (insulin-dependent) diabetes mellitus in humans as well as in most of its animal models is T-cell dependent [1] but a significant contribution of macrophages to disease development was noted. Macrophage directed immune intervention prevents diabetes development, macrophages precede $\mathrm{T}$ cells in islet inflammation [1], macrophages lyse islet cells in vitro [2] and macrophage products interleukin 1(IL-1) and tumour necrosis factor $\alpha(\mathrm{TNF} \alpha)$ interfere with islet Beta-cell function and viability $[3,4]$.

This particular role of macrophages in diabetes pathogenesis prompted us to search for defects of macrophage function in BB rats. We have analysed the production by macrophages of TNF $\alpha$, a major immunoregulatory, proinflammatory and cytotoxic cytokine.

\section{Materials and methods}

\section{Rats and macrophage isolation}

Peritoneal macrophages of diabetes-prone BB/W Dus rats, diabetes resistant BB/WD rats (both 65-70 days of age) and Wistar Wi/Han rats (65-90 days of age, kindly provided by Dipl. Biol. U.Kiesel, Düsseldorf, FRG) were activated in vivo by i.p. injection of $500 \mu \mathrm{l}$ of heat inactivated Corynebacterium parvum (Wellcome, Burgwedel, FRG). Peritoneal cells were isolated four days later by peritoneal lavage and macrophages were enriched by adherence for $2 \mathrm{~h}\left(37^{\circ} \mathrm{C}\right.$, $5 \% \mathrm{CO}_{2}$ ) in RPMI 1640 with $10 \%$ fetal calf serum (FCS) on plastic dishes coated with FCS. Adherent cells were detached by incubation with $3 \mathrm{ml}$ ice-cold $\mathrm{Ca}^{2+}, \mathrm{Mg}^{2+}$-free Hank's Balanced salt solution (Merck, Darmstadt, FRG) with $25 \mathrm{mmol} / 1$ EDTA for $7 \mathrm{~min}$. Bone marrow cells were isolated by flushing femora of 58-66 days old animals followed by culture in RPMI 1640 plus $15 \%$ colony stimulating factor 1 (CSF-1) containing medium at a concentration of $4 \times 10^{6}$ cells/ml for 4 days and a further $24 \mathrm{~h}$ in RPMI $1640+10 \%$ FCS. Supernatants of cultures of $L 929$ cells $\left(2 \times 10^{5} \mathrm{cells} / \mathrm{ml}\right)$ were used as source of CSF-1.

\section{Analysis of TNF production}

Adherent peritoneal cells $\left(1 \times 10^{6} \mathrm{cells} / \mathrm{ml}\right)$ were incubated over night in RPMI 1640 with $10 \%$ FCS and afterwards stimulated in vitro with $1 \mu \mathrm{g} / \mathrm{ml}$ lipopolysaccharide (LPS from Escherichia coli 0 26: B6, Sigma, Munich, FRG) and supernatant withdrawn after 0,5 and $25 \mathrm{~h}$. Bone marrow derived macrophages were stimulated with $1 \mu \mathrm{g} / \mathrm{ml}$ LPS or with $10 \mathrm{ng} / \mathrm{ml}$ LPS plus $100 \mathrm{U} / \mathrm{ml}$ recombinant rat interferon gamma (Holland Biotechnology bv, Leiden, Netherlands). TNF $\alpha$ was quantitated by a bioassay using L929 cells as described [5]. Control experiments were performed with a rabbit anti murine TNF $\alpha$ serum (not crossreacting with TNF $\beta$, kind gift of Dr. G. R. Adolf, Boehringer-Institute, Vienna, Austria). Of the antiserum $116 \mathrm{nl}$ were found to neutralise one unit of recombinant murine TNF $\alpha$ (Genzyme, Boston, Mass., USA). Characterization of peritoneal and bone marrow cells was done by immunochemistry as described previously [2] by using mouse anti-rat mAb: W3/25 specific for CD4 marker on a fraction of macrophages and T lymphocytes; W3/13 specific for lymphocytes and polymorphonuclear cells; $0 \times 19$ specific for T lymphocytes; $0 \times 8$ specific for $\mathrm{CD} 8$ marker on a fraction of $\mathbf{T}$ lymphocytes and Natural Killer cells (all from CamonSerotec, Wiesbaden, FRG); ED1 specific for a cytoplasmic vacuole antigen on some free and tissue macrophages and ED2 specific for a 
Table 1. Characterization of adherent peritoneal and bone marrow derived cells from diabetes prone, diabetes resistant BB and normal Wistar rats

\begin{tabular}{|c|c|c|c|c|c|}
\hline \multirow[b]{2}{*}{$\begin{array}{l}\text { Monoclonal } \\
\text { antibody }\end{array}$} & \multicolumn{3}{|c|}{ Adherent peritoneal cells } & \multicolumn{2}{|c|}{ Adherent bone marrow derived cells } \\
\hline & $\begin{array}{l}\text { Diabetes } \\
\text { prone } \mathrm{BB}\end{array}$ & $\begin{array}{l}\text { Diabetes } \\
\text { resistant BB }\end{array}$ & $\begin{array}{l}\text { Wistar } \\
\text { (\% positive cells) }\end{array}$ & $\begin{array}{l}\text { Diabetes } \\
\text { prone BB }\end{array}$ & Wistar \\
\hline ED1 & $>95$ & $>95$ & $>95$ & $91 \pm 1.5$ & $93 \pm 1.5$ \\
\hline ED2 & $4.0 \pm 0.5$ & $4.5 \pm 0.4$ & $3.9 \pm 0.6$ & $8 \pm 1.7$ & $6 \pm 1.4$ \\
\hline $\mathrm{W} 3 / 25$ & $8.5 \pm 1.4$ & $7.3 \pm 1.0$ & $7.8 \pm 1.3$ & $7 \pm 3.2$ & $8 \pm 2.5$ \\
\hline $\mathrm{W} 3 / 13$ & $6.0 \pm 0.9$ & $6.5 \pm 1.0$ & $5.9 \pm 1.2$ & $8 \pm 2.7$ & $8 \pm 3.2$ \\
\hline Ox 19 & $2.0 \pm 1.1$ & $2.5 \pm 0.8$ & $2.2 \pm 1.0$ & $5 \pm 2$ & $6 \pm 1.8$ \\
\hline Ox 8 & $<1$ & $<1$ & $<1$ & $2 \pm 1$ & $2 \pm 1$ \\
\hline Asialo GM1 & $<1$ & $<1$ & $<1$ & $1 \pm 1$ & $1 \pm 1$ \\
\hline
\end{tabular}

Peritoneal macrophages were enriched by adherence for $2 \mathrm{~h}\left(37^{\circ} \mathrm{C}, 5 \% \mathrm{CO}_{2}\right)$ on plastic dishes coated with fetal calf serum. The adherent fraction contained a mean of $33 \times 10^{6}$ cells for diabetes prone BB $(n=5), 20 \times 10^{6}$ for diabetes resistant BB $(n=7)$ and $45 \times 10^{6}$ for Wistar rats $(n=10)$. Adherent bone marrow cells were analysed after culture for $4+1$ days (see Materials and methods)

membrane antigen on some tissue macrophages (kind gift of Dr. C.D.Dijkstra, Amsterdam, Netherlands); anti-asialo GM1 (Wako Chemicals GmbH, Neuss, FRG) specific for Natural Killer cells and some T cells.

Screening of pancreata for insulitis was done by preparation of haematoxylin-eosin stained sections of Bouin-fixed, paraffin embedded pancreata and reading of coded slides by two observers.

\section{Results}

Peritoneal macrophages were harvested from diabetes prone, diabetes resistant BB rats or normal Wistar rats after activation in vivo with Corynebacterium parvum. Comparable numbers of macrophages were isolated in the three strains and their purity and the expression of ED1 and ED2 markers were highly similar (Table 1). Macrophages were restimulated in vitro with lipopolysaccharide and the culture supernatant withdrawn at $0,5,7$ or $25 \mathrm{~h}$ for determination of its TNF $\alpha$ content. As shown in Table 2 basal and maximal TNF $\alpha$ secretion was strikingly higher in macrophages from diabetes prone BB rats (basal: $24 \mathrm{U} / 10^{6}$ cells; peak $1300 \mathrm{U} / 10^{6}$ cells) than in macrophages from diabetes resistant $\mathrm{BB}$ rats (basal $<0.5 \mathrm{U} / 10^{6}$ cells). The latter results were similar as seen with macrophages from Wistar rats.

Table 2. Enhanced TNF $\alpha$ secretion by macrophages from diabetes prone $\mathrm{BB}$ rats

\begin{tabular}{|c|c|c|c|c|c|}
\hline \multirow[b]{2}{*}{$\begin{array}{l}\text { Peritoneal } \\
\text { macrophages }\end{array}$} & \multirow[b]{2}{*}{$n$} & \multirow{2}{*}{$\begin{array}{l}\text { Stimula- } \\
\text { tion in vitro }\end{array}$} & \multicolumn{3}{|c|}{$\begin{array}{l}\text { TNF } \alpha \text { secretion } \\
\left(\mathrm{U} / 10^{6} \text { cells } \pm \mathrm{SD}\right)\end{array}$} \\
\hline & & & $\mathrm{Oh}$ & $5 \mathrm{~h}$ & $25 \mathrm{~h}$ \\
\hline Diabetes prone $\mathrm{BB}$ & 5 & LPS & $24 \pm 2$ & $1300 \pm 25$ & $208 \pm 9$ \\
\hline Diabetes resistant $\mathrm{BB}$ & 7 & LPS & $<0.5$ & $52 \pm 4$ & $4 \pm 1$ \\
\hline Wistar & 10 & LPS & $<0.5$ & $36 \pm 3$ & $2 \pm 1$ \\
\hline \multicolumn{6}{|c|}{ Bone marrow derived macrophages } \\
\hline Diabetes prone $\mathrm{BB}$ & 7 & $\begin{array}{l}\text { LPS } \\
\text { LPS + } \\
\text { IFN } \gamma\end{array}$ & $\begin{array}{l}<0.5 \\
<0.5\end{array}$ & $\begin{array}{l}136 \pm 39 \\
147 \pm 5\end{array}$ & $\begin{array}{l}<0.5 \\
<0.5\end{array}$ \\
\hline Wistar & $\begin{array}{l}7 \\
4\end{array}$ & $\begin{array}{l}\text { LPS } \\
\text { LPS + } \\
\text { IFN } \gamma\end{array}$ & $\begin{array}{l}<0.5 \\
<0.5\end{array}$ & $\begin{array}{l}30 \pm 3 \\
64 \pm 17\end{array}$ & $\begin{array}{l}<0.5 \\
<0.5\end{array}$ \\
\hline
\end{tabular}

Adherent bone marrow derived cells contained more than $90 \%$ of $\mathrm{ED} 1^{+}$macrophages for both diabetes prone $\mathrm{BB}$ and Wistar rats (Table 1). These cells were activated in vitro with LPS or a combination of LPS and IFN $\gamma$. In both cases macrophages from diabetes prone BB rats secreted higher amounts of TNF $\alpha$ than were found for cells from Wistar rats. Diabetes resistant BB rats were not available for this study. Control experiments were performed to verify that the cytokine measured by the L929 bioassay was TNF $\alpha$ and not a related cytokine such as TNF $\beta$. Macrophage culture supernatants from the three rat strains were mixed with $1 / 100$ volume of the TNF $\alpha$ antiserum or with rabbit normal serum. Lysis of L929 cells was completely blocked in the presence of the TNFo antiserum (less than $5 \%$ lysis above background levels in each instance).

Of the diabetes prone $\mathrm{BB}$ rats a total of 106 islets were analysed for signs of islet inflammation. We found two islet sections $>10$ mononuclear cells infiltrated and one islet section showed a small cluster of five infiltrating cells. All the other islet sections were devoid of recognizable pathological changes.

\section{Discussion}

After i.p. injection of C. parvum activated macrophages of similar number and phenotype could be isolated from normal Wistar rats and from age- and sex-matched diabetes prone or diabetes resistant BB rats. Even so, striking differences were found in the levels of basal and LPS-induced TNF $\alpha$-production. Macrophages from diabetes-resistant $\mathrm{BB}$ rats lacked demonstrable basal TNF $\alpha$-production and responded moderately to the LPSstimulus. Similar kinetics were seen in Wistar rats. In contrast, macrophages from diabetes prone $\mathrm{BB}$ rats showed higher basal TNF $\alpha$-levels in the supernatant as well as enhanced peak concentrations. For convenience the enhanced TNF $\alpha$-level in supernatants of activated macrophages is termed TNF $\alpha$ hypersecretion. However, it must be noted that decreased removal/degradation of secreted $\mathrm{TNF} \alpha$ may also be involved. Preliminary experiments show enhanced TNF $\alpha$ mRNA levels (unpublished observations). 
Upregulated TNF $\alpha$ production was observed in nondiabetic $\mathrm{BB}$ rats. In fact, at the time of peritoneal cell harvest $B B$ rats showed only minimal signs of insulitis.

It is of interest that a difference in TNF $\alpha$ secretion between diabetes prone BB and Wistar rats was also found when macrophages derived from bone marrow cells by in vitro culture were tested. This finding indicates that the regulatory defect described is endogenous to this cell lineage. Studies are underway to determine whether TNF $\alpha$ hypersecretion is genetically linked with other immune cell abnormalities in the BB rat such as lymphopoenia and the defect in RTb expression by $\mathrm{T}$ cells.

TNF $\alpha$ is a proinflammatory cytokine of which overproduction may favour chronic local inflammation such as pancreatic insulitis. In addition, TNF $\alpha$ in conjunction with interleukin 1 and interferon gamma shows direct toxic effects on islet cells in vitro [4]. Finally, TNF $\alpha$ is a co-stimulatory signal during antigen presentation. Upregulated TNF $\alpha$ production may interfere with proper thymic and post-thymic T-cell stimulation/maturation and thereby promote islet autoimmunity.

Abnormal cytokine release by macrophages has been described recently in several autoimmune diseases. In some cases cytokine secretion is enhanced [6], in others it is decreased [7]. In spontaneously diabetic NOD mice TNF $\alpha$ production is decreased and exogenous TNF $\alpha$ may even prevent diabetes development [8]. In human Type 1 diabetes HLA-DR types conferring protection seem to be associated with decreased TNF $\alpha$ secretion by monocytes, but a general consensus has not yet been reached $[9,10]$. We therefore assume that aberrant TNF $\alpha$ production in general, be it increased or decreased, contributes to immune dysregulation thus favouring the development of autoimmunity.

Ackowledgements. We thank Prof. V.Kolb-Bachofen for analysis of pancreas histology and Mrs. C.Bergemann for typing the manuscript. This work was supported by the Bundesminister für Jugend, Familie, Frauen und Gesundheit and the Minister fur Wissenschaft und Forschung des Landes Nordrhein Westfalen.

\section{References}

1. Hanenberg H, Kolb-Bachofen V, Kantwerk-Funke G, Kolb H (1989) Macrophage infiltration precedes and is a prerequisite for lymphocytic insulitis in pancreatic islets of prediabetic BB rats. Diabetologia 32: 126-134

2. Appels B, Burkart V, Kantwerk-Funke G, Funda J, KolbBachofen V, Kolb H (1989) Spontaneous cytotoxicity of macrophages against pancreatic islet cells. J Immunol 142: 3803-3808

3. Mandrup-Poulsen T, Bendtzen K, Nerup J, Dinarello CA, Svenson M, Nielson JH (1986) Affinity-purified human Interleukin-I is cytotoxic to isolated islets of Langerhans. Diabetologia 29: 6367

4. Pukel C, Baquerizo H, Rabinovitch A (1988) Destruction of rat islet cell monolayers by cytokines: synergistic interactions of Interferon-gamma, Tumour Necrosis Factor, Lymphotoxin and Interleukin I. Diabetes 37: 133-136

5. Unglaub R, Maxeiner B, Thoma B, Pfizenmeier K, Scheurich $P$ (1987) Downregulation of Tumour Necrosis Factor sensitivity via modulation of TNF binding capacity by protein kinase Cactivators. J Exp Med 166: 1788-1797

6. Buchan G, Barrett K, Turner M, Chantry D, Maini RN, Feldmann M (1988) Interleukin-1 and tumour necrosis factor mRNA expression in rheumatoid arthritis: prolonged production of IL10. Clin Exp Immunol 73: 449-455

7. Jacob CO, McDevitt HO (1988) Tumour necrosis factor- $\alpha$ in murine autoimmune 'Lupus' nephritis. Nature 331: 356-358

8. Satoh J, Seino H, Abo T, Tanaka S, Shintani S, Ohta S, Tamura $K$, Sawai $T$, Nobunaga $T$, Oteki T, Kumagai K, Toyota $T$ (1989) Recombinant human tumour necrosis factor $\alpha$ suppresses autoimmune diabetes in nonobese diabetic mice.J Clin Invest 84 : $1345-1348$

9. Bendtzen K, Morling N, Fomsgaard A, Svenson M, Jakobsen B, Odum N, Svejgaard A (1988) Association between HLA-DR 2 and production of tumour necrosis factor $\alpha$ and interleukin 1 by mononucleated cells activated by lipopolysaccharide. Scan J Immunol 28: 599-606

10. Molvig J, Worsaa H, Wogensen L, Bach L, Nielsen LS, Nerup J (1989) Monocyte functions in Type 1 (insulin-dependent) diabetes mellitus. Diabetologia 32: $518 \mathrm{~A}$

Received: 2 March 1990

and in revised form: 8 May 1990

Prof.Dr. H. Kolb

Diabetes Research Institute

University of Düsseldorf

Auf'm Hennekamp 65

D-4000 Düsseldorf 1, FRG 